\title{
Isolation and Characterization of Bacteria from the Gut of Blue Gourami (Trichogaster tricopters) and its Role on Growth
}

\section{G. Deepika, P. Sivakumar and M.R. Rajan* (D)}

Department of Biology, Gandhigram Rural Institute- Deemed to be University, Gandhigram - 624 302, Tamil Nadu, India.

\begin{abstract}
Five variant groups were isolated from the gut of Blue gourami Trichogaster tricopterus through serial dilution, identified by using biochemical tests and bacteria were Bacillus sp., (G1) Pseudomonas sp., (G2) Enterobacter sp., (G3) Aeromonas sp., (G4) and Escherichia sp., (G5). Based on enzymatic productivity (Amylase, Cellulase, Lipase, and Protease) and antimicrobial activity Bacillus sp., Enterobacter sp., and Aeromonas sp., and mass multiplied using nutrient broth. Four different feeds such as feed I (Control), II (1 $\mathrm{ml}$ Bacillus sp.,) III (1 $\mathrm{ml}$ each of Bacillus sp. and Enterobacter sp.) and IV (1 $\mathrm{ml}$ each of Bacillus sp., Enterobacter sp. and Aeromonas sp.,) were prepared. Feed utilization parameters of blue gourami Trichogaster tricopterus were studied after $\mathbf{2 1}$ days of rearing and all feed utilization parameters were higher in feed IV.

Keywords: Gut bacteria, blue gourami, in vivo trial, growth parameters.
\end{abstract}

*Correspondence: mrrajanbio@gmail.com

(Received: 30 October 2019; accepted: 16 December 2019)

Citation: G. Deepika, P. Sivakumar and M.R. Rajan, Isolation and Characterization of Bacteria from the Gut of Blue Gourami (Trichogaster tricopters) and its Role on Growth, J Pure Appl Microbiol., 2019; 13(4):2479-2487. https://doi.org/10.22207/ JPAM.13.4.63

(C) The Author(s) 2019. Open Access. This article is distributed under the terms of the Creative Commons Attribution 4.0 International License which permits unrestricted use, sharing, distribution, and reproduction in any medium, provided you give appropriate credit to the original author(s) and the source, provide a link to the Creative Commons license, and indicate if changes were made. 


\section{INTRODUCTION}

Ornamental fish rearing has emerged as the second most popular hobby next to photography due to its aesthetic beauty (Aly et al., 2008). The trade-in ornamental fish and aquarium supplies are multi-million dollar industries that span the globe, with a retail value of approximately US\$ 500 million. Besides this, it also provides employment and revenue generation for the country (Balacazar, 2006). The major problem facing aquaculturists is the uncontrollable mortalities associated with disease and related disorders. Since the economic importance of aquarium fish is not less than that of the food fish. Ornamental fishes are susceptible to bacteria, viral, fungi, protozoa, and parasitic organisms and cause loss to the produce. Among the various pathogens affecting the cultured fish species, bacteria cause severe damage. Control of the bacterial disease is made possible by using drugs and antibiotics. The traditional use of antibiotics as growth promoters in aquaculture has been challenged because of the potential development of antibiotic-resistant bacteria. The use of vaccines is laborious, costly and highly stressful to the animals. Since these methods have certain limitations, alternative, productive methods must be examined to reduce the incidence of the pathogen in ornamental fish culture. The bacterial community in the gut of aquatic animals is much more crowded compared to terrestrial animals, as water serves an ideal medium for bacterial growth. The microbial network in the gastrointestinal tract of fish is very complex and plays a vital role in fish nutrition and disease prevention. The composition of the community of microbes in the fish gut is not constant and may change with nutritional status, age, surrounding water and other environmental conditions (Banerjee and Ray, 2017). However, the microbial balance in the gastrointestinal tract is crucial in response to host metabolism, disease prevention, and physiology. The microbial composition in the gut of vertebrates, including fish largely depends on the nutritional status of the host. Protease producing bacterial communities is dominant flora in carnivorous animals, which helps to degrade complex proteins to simple amino acids. Similarly, amylase and cellulose producing bacterial communities are reported to be highest in herbivorous animals (Ray et al. 2012). In addition to host nutrition, the gastrointestinal microbiota serves a variety of other beneficial functions in the host such as preventing the colonization of infectious agents, energy homeostasis and maintenance of healthy mucosal immunity. The normal microflora in the intestinal tract of the fish includes Pseudomonas spp. Aeromonous spp., Enterobacteriaceae spp., Micrococcus spp., Escherichia spp, and Bacillus spp and these bacteria play a vital role in fish nutrition and disease prevention. Bairagi et al. (2002) have reported the existence of several enzymes producing bacterial strains, isolated from different freshwater fishes having different feeding habits. The study related to the isolation and characterization of bacteria from the gut of Blue Gourami Trichogaster tricopterus and its role in growth is entirely absent. So present research was undertaken.

\section{MATERIALS AND METHODS Fish collection}

For the present study, Blue gourami, Trichogaster tricopterus were collected from Aqua Garden, Madurai, Tamil Nadu, India and transported to the laboratory in polyethylene bags filled with aerated water. Fishes were acclimated in glass aquaria $\left(60^{\prime} 45^{\prime} 45 \mathrm{~cm}\right.$ ) for 15 days at 28 $\pm 2^{\circ} \mathrm{C}$. During acclimation fishes were fed with trainee feed containing fish meal, groundnut oil cake, wheat flour and rice bran in the form of dry Pellets.

\section{Isolation of gut bacteria}

After transportation to the laboratory the gut content of Blue gourami was collected, consequently diluted and $10^{-6}$ was selected for the separation of bacteria. The diluted sample was plated over sterilized nutrient agar medium and incubated at $37^{\circ} \mathrm{C}$ for 24 hours. (Bergy's Manual of Determinative Bacteriology, 1994). Nutrient Agar was used for the present study, different incubation temperature was used to obtain a wider range of isolation and the incubation time ranges from 24 hours, depending on the incubation temperature, groups were enumerated and separated.

\section{Characterization of gut bacteria}

The preponderant groups on the nutrient agar medium were selected and identified based on the cellular morphology, microscopic and 
biochemical characteristics. The tests used for examining the colonies were Indole, Methyl Red, Vogues Prokauser, Citrate, Catalase, Gelatin hydrolysis, Starch, Oxidize test, Sucrose and lipase test and identified at the genus level of bacteria (Rajan and Selvi Christy, 2010). The gut bacteria of blue Gourami were examined for the production of digestive enzymes like Amylase, Cellulase, Lipase, and Protease using selective media. (Muge Aliye Hekimoglu et al., 2014). Selected gut bacteria were examined for Double-layer Screening Antibacterial activity using selective media. (Jawahar Abraham, 2008). The different pathogens selected are Staphylococcus aureus, Shigella sonnei, Enterococcus faecalis, Pseudomonas aeruginosa, and Klebsiella pneumonia. The isolated Bacillus species, Enterobacter species, Aeromonas species ( $10^{-6}$ Cells) were mass multiplied by inoculating into the nutrient broth.

\section{Experimental Feed Preparation:}

The raw materials such as fish meal, groundnut oil cake, wheat flour, and tapioca were used for preparing the feed. After knowing the protein content by Micro - Kjeldahl method (Jayaraman,1992) (Table 1), one control(without bacteria), three experimental feeds (Ali, 1980) were prepared by using different isolated bacteria. The components used for feed preparation were dried, powdered and sieved through 425- micron sieve. The ingredients were weighed and mixed thoroughly with $130-150 \mathrm{ml}$ of distilled water.
The mixed feedstuff was put in an autoclave for $15 \mathrm{~min}$ at $100^{\circ} \mathrm{C}$ and cooled. After cooling, fish oil, sunflower oil, supplevite - mix, sodium chloride, sodium benzoate, and different isolated $(1 \mathrm{ml}$ of Bacillus sp., $1 \mathrm{ml}$ of Bacillus sp., +Enterobactor $\mathrm{sp}$. , and $1 \mathrm{ml}$ of Bacillus sp.,+ Enterobacter sp., and Aeromonas sp.,) bacteria were mixed with the feed. And then it was extruded with the help of Pelletizer. The pellets were dried at room temperature. This formulated feed was kept in an airtight container in $-20^{\circ} \mathrm{C}$ until used to prevent contamination (Table 2).

\section{In vivo experimental design and growth study}

For growth study, uniform size of Blue gourami Trichogaster tricopterus ( $3.66 \pm 0.36 \mathrm{~g}$ ) were selected and were introduced in rectangular glass tanks $(45 \mathrm{~cm} \mathrm{L'} 22 \mathrm{~cm} \mathrm{~B}$ ' $22 \mathrm{~cm} \mathrm{H}$ ) having a capacity of 18 liters. Five fishes were introduced in each tank and triplicates were maintained. During rearing, the fishes were fed on the ad libitum diet of the prepared feed twice a day for 1 hour each from $9-10$ am and $4-5 \mathrm{pm}$. The unfed were collected after one hour of feeding

Table 1. Protein level of Major ingredients

\begin{tabular}{lcc}
\hline S.No. & Ingredients & $\begin{array}{c}\text { Percentage of } \\
\text { Protein }\end{array}$ \\
\hline 1 & Fish meal & 58 \\
2 & Groundnut oil cake & 44 \\
3 & Wheat flour & 11 \\
4 & Tapioca & 03 \\
\hline
\end{tabular}

Table 2. Composition of different ingredients in Experimental feed (g/100gm)

\begin{tabular}{lccccc}
\hline S.No. & Ingredients & \multicolumn{4}{c}{ Experimental Feeds } \\
\cline { 3 - 5 } & & $\begin{array}{c}\text { Feed I } \\
\text { (Control) }\end{array}$ & Feed II & Feed III & Feed IV \\
\hline 1 & Fishmeal & 36.2 & 36.2 & 36.2 & 36.2 \\
2 & GNOC & 36.2 & 36.2 & 36.2 & 36.2 \\
3 & Wheat flour & 8.7 & 8.7 & 8.7 & 8.7 \\
4 & Topioca & 8.7 & 8.7 & 8.7 & 8.7 \\
5 & Fish oil & 2 & 2 & 2 & 2 \\
6 & Sunflower oil & 2 & 2 & 2 & 4 \\
7 & Suppelvite mix & 4 & 4 & 4 & 1 \\
8 & Sodium chloride & 1 & 1 & 1 & 1 \\
9 & Sodium benzoate & 1 & 1 & 1 1ml Bacillus sp. & 1 ml Bacillus sp. \\
10 & Microbes & - & 1ml Bacillus sp. & 1ml Enterobacter sp. & $1 \mathrm{ml}$ Enterobacter sp \\
& & & & & $1 \mathrm{ml}$ Aeromonas sp.
\end{tabular}


Table 3. Biochemical characterization of intestinal bacteria of Blue Gourami

\begin{tabular}{lccccc}
\hline Test & G1 & G2 & G3 & G4 & G5 \\
\hline Simple staining & Rods & Cocci & Rods & Rods & Rods \\
Gram's staining & Negative & Positive & Negative & Positive & Negative \\
Mortility Test & Motile & Motile & Motile & Motile & Motile \\
Indole test & Negative & Positive & Positive & Positive & Positive \\
Methyl Red & Positive & Positive & Positive & positive & Positive \\
Voges Prokauser & Negative & Positive & Positive & Positive & Positive \\
Citrate test & Positive & Positive & Negative & Positive & Positive \\
Catalase test & Positive & Positive & Positive & Positive & Positive \\
Starch test & Positive & Negative & Negative & Positive & Negative \\
Gelatin hydrolysis & Positive & Negative & Negative & Positive & Negative \\
Oxidase Test & Positive & Negative & Negative & Positive & Negative \\
Lactose Test & Positive & Negative & Negative & Positive & Positive \\
Sucrose Test & Positive & Positive & Not -performed & Positive & Positive \\
Lipid Test & Positive & Positive & Positive & Positive & Positive \\
Identification & Bacillus & Pseudomonas & Enterobacter & Aeromonas & Escherichia \\
result & sp. & sp. & sp. & sp. & sp. \\
\hline
\end{tabular}

without disturbing the fishes. The unfed was dried to constant weight. The faecal matter was collected daily before changing the water with the least disturbance to the fishes and dried at $95^{\circ} \mathrm{C}$. Approximately $70 \%$ of the water in the tank was replaced with tap water. The experiment was continued for 21 days. On the $21^{\text {st }}$ day, the length and weight of the fishes were measured in live conditions. Feed Utilization Parameters such as condition factor (K), Feed consumption, Feed Conversion Efficiency, Feed Conversion Ratio, Growth, Percentage Growth Rate, Relative Growth Rate, Assimilation, Metabolism, Gross Growth Efficiency and Net Growth Efficiency were calculated.

\section{RESULTS AND DISCUSSION}

The organisms isolated from the intestinal content were identified Bacillus sp, Enterobacter $\mathrm{sp}$, Aeromonas sp., using biochemical tests as given in table 3 . The selected intestinal bacteria were Bacillus sp., Enterobacter sp., Aeromonas sp., based on the Biochemical tests, Enzyme Production (Amylase, Cellulase, Lipase, and Protease) (Table 4). Based on the test the selected Bacillus sp., Enterobacter sp, Aeromonas sp., (G1), (G3), (G4) found to be producing a higher amount of digestive enzymes. Liu et al. (2016) reported that the gut micro biome of eight fish species comprising a relatively large number of bacteria predominantly Proteobacteria, Firmicutes, Bacteroidetes, and Acidobacteria. Ray et al. (2012) reported the isolation of amylase, cellulase, lipase and protease producing bacteria from the gut of different fishes. Banerjee et al. (2013) reported that the amylase producing bacteria were higher than cellulose producing bacteria in the gastrointestinal tract of two Indian air breathing fishes. Parmita Das et al. (2014) reported the isolation of amylase, cellulase, protease, and lipase

Table 4. Enzyme Productivity of Intestinal bacteria of Blue Gourami

\begin{tabular}{lccccc}
\hline S.No & Intestinal bacteria & Amylase & Cellulase & Lipase & Protease \\
\hline 1 & G1(Bacillus sp.,) & +++ & ++ & ++ & +++ \\
2 & G2(Pseudomonas sp.,) & + & + & ++ & + \\
3 & G3(Enterobacter sp.,) & ++ & ++ & ++ & +++ \\
4 & G4 (Aeromonas sp.,) & ++ & +++ & ++ & ++ \\
5 & G5 (Escherichia sp.,) & ++ & ++ & ++ & ++
\end{tabular}

+ - Nil(Absent )or (Negative) ++ - Low productivity (Positive) +++ - Higher productivity (Positive). 
producing bacterial strains in the digestive tract of 4 brackish water fish species.

Antibacterial Activity (Table 5), and enumeration of bacteria are given in Table 6. Based on antibacterial activity Bacillus sp., Enterobacter sp., Aeromonas sp., (G1), (G3), (G4) has shown higher inhibition against pathogens Staphylococcus aureus, Shigella sonnei, Enterococcus faecalis, Pseudomonas aeruginosa and Klebsilla pneumoniae. Zapata et al. (2013) reported that Lactic acid bacterial strains isolated from Nile Tilapia intestine showed the high ability to inhibit the growth of freshwater fish pathogen particularly Vibrio sp. and Mycobacterium sp. Shubhankar Ghosh et al. (2014) reported the antibacterial activity of Lactic acid bacteria isolated from the gut of marine fish Rastrelliger kanagurta against fish, shrimp and human pathogens. Banerjee et al. (2016) reported that the Bacillus subtilis isolated from the gastrointestinal tract of Labeo rohita showed inhibitory activity against four fish pathogens such as Bacillus mycoides, Aeromonas salmonicida, Pseudomonas fluorescens and Aeromonas hydrophila. The intestinal bacteria Enterobacter sp., isolated from the intestine of Labeo rohita showed higher zone of inhibition of fish pathogens of Staphylococcus aereus (P1), Shigella sonnei (P2), Enterococcus faecalis (P3), Pseudomonas aeruginosa (P4) and Klebsilla pneumonia (P5) (Sivakumar et al. 2017). Agustina et al.(2018) reported that 19 bacteria isolated from the gut of Kelabau fish showed antibacterial activity against Aeromonas hydrophila and Pseudomonas sp. Mukherjee et al. (2019) reported that the gut bacteria Bacillus methylotrophicus, $B$. amyloliquefaciens, Pseudomonas fluorescens and $B$. licheniformis isolated from rohu, Labeo rohita were antagonistic to fish pathogen Aeromonas spp.,

Condition factor of Blue gourami Trichogaster tricopterus reared in different feeds were presented in Table 7. Condition factor (K)

Table 5. Antibacterial Activity (Double layer screening) of intestinal bacteria of Blue Gourami

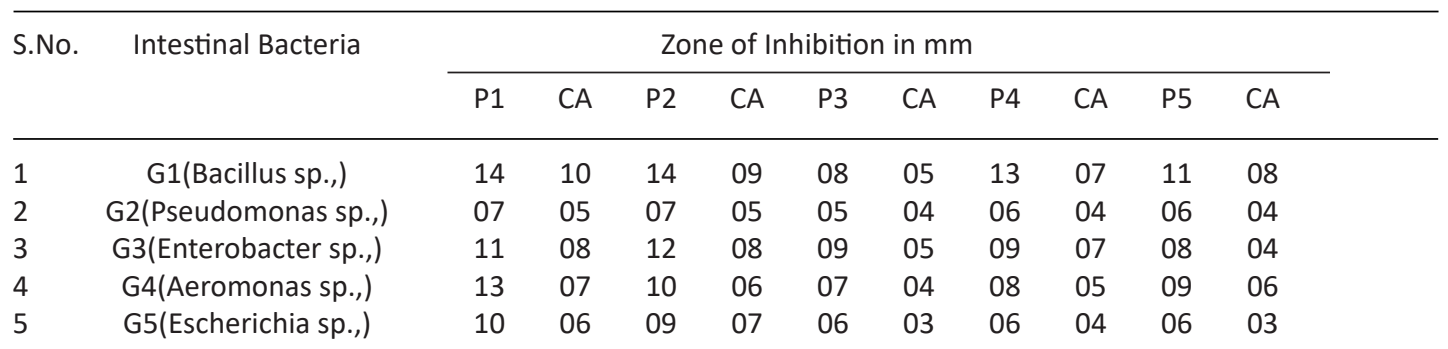

CA - Commercial Antibiotic (Zendamycin)P1 - Staphylococcus aureus P2 - Shigella sonnei

P3 - Enterococcus faecalis P4 - Pseudomonas aeruginosa P5 - Klebsiella pneumonia

Table 6. Enumeration of Intestinal bacteria of Blue Gourami

\begin{tabular}{|c|c|c|c|c|}
\hline S.No & Intestinal Bacteria & $\begin{array}{l}\text { Sample (Intestine of } \\
\text { Blue Gourami) }\end{array}$ & $\begin{array}{c}\text { No. of } \\
\text { colonies }\end{array}$ & $\begin{array}{l}\mathrm{CFU} / \mathrm{ml} \text { of } \\
\text { the sample }\end{array}$ \\
\hline \multirow[t]{2}{*}{1.} & G1(Bacillus sp.,) & $10^{-6}(0)$ & 111 & $110 \times 10^{6}$ \\
\hline & & $10^{-6}(\mathrm{R})$ & 101 & \\
\hline \multirow[t]{2}{*}{2.} & G2(Pseudomonas sp.,) & $10^{-6}(0)$ & 103 & $101 \times 10^{6}$ \\
\hline & & $10^{-6}(\mathrm{R})$ & 112 & \\
\hline \multirow[t]{2}{*}{3.} & G3(Enterobacter sp.,) & $10^{-6}(0)$ & 114 & $111 \times 10^{6}$ \\
\hline & & $10^{-6}(\mathrm{R})$ & 108 & \\
\hline \multirow[t]{2}{*}{4.} & G4 (Aeromonas sp.,) & $10^{-6}(0)$ & 109 & $106 \times 10^{6}$ \\
\hline & & $10^{-6}(\mathrm{R})$ & 111 & \\
\hline \multirow[t]{2}{*}{5.} & G5 (Escherichia sp.,) & $10^{-6}(0)$ & 110 & $110 \times 10^{6}$ \\
\hline & & $10^{-6}(R)$ & 111 & \\
\hline
\end{tabular}

O-Original, R- Replica. 
of blue gourami Trichogaster tricopterus was estimated for comparative purposes to assess the feed. The average initial condition factor is 1.15 \pm 0.13 and the final condition factor increased in feed IV $(1.55 \pm 0.18)$ and in all others, the final condition factor was decreased. Sivakumar et al., (2016) reported that the average initial condition factor of yellow molly was 1.84 and the final condition factor increased in feed $\mathrm{V}$ (2.65) when fed with Escherichia fergusonii. Suganya et al. (2018) also reported that the final condition factor was higher in feed containing $4 \mathrm{ml}$ of Pseudomonas sp. in the feed of Zebrafish.

Feed utilization parameters of blue gourami Trichogaster tricopterus is presented in Table 8. Feed consumption of Blue gourami was higher in feed IV $(5,4 \pm 0.13)$ containing every $1 \mathrm{ml}$ each of Bacillus sp., Enterobacter sp., Aeromonas sp. and lower in feed I (control) $(3.1 \pm 0.41)$. Rajan and Revathi (2011) reported that the feed consumption of Platy Xiphophorus maculates was higher in Ex. Feed $\mathrm{V}$ containing $10^{4}$ cells

Table 7. Condition factor(K) of Blue Gourami

\begin{tabular}{lcc}
\hline Feeds & Intial & Final \\
\hline EX. Feed I & $1.15 \pm 0.13$ & $1.21 \pm 0.17$ \\
EX. Feed II & $1.10 \pm 0.05$ & $1.33 \pm 0.15$ \\
Ex. Feed III & $1.15 \pm 0.04$ & $1.44 . \pm 0.16$ \\
Ex. Feed IV & $1.36 \pm 0.08$ & $1.55 \pm 0.18$ \\
\hline
\end{tabular}

of Bacillus subtilis. Bisht et al., (2012) reported that the feed consumption in common carp was higher (95\%) in diet D3 and lower (85\%) in diet D1. Wang et al. (2015) reported that the feed intake was higher in juvenile Pseudobagrus ussuriensis. Feed Conversion Efficiency of Blue gourami was higher in feed IV $(0.06 \pm 0.01)$. But in the case of gold fish, the feed conversion efficiency gradually decreased from lower to a higher quantity of Pseudomonas sp. (Rajan and Jeyachristina Arokia Selvi, 2014). Feed Conversion Ratio (FCR) of Blue gourami was lower in feed IV $(4.46 \pm 0.53)$ and higher in feed I (8.41 \pm 0.23$)$.Suganya et al. (2018) reported that the Feed Conversion Ratio (FCR) of Zebra fish was lower in feed V $(0.03 \pm 0.01)$ and higher in feed I $(0.13 \pm 0.02)$ Somrudee Silarudee et al. (2019) reported such lower feed conversion ratio (FCR) in Black Eared Catfish (Pangasius larnaudii) fed with Lactobacillus plantarum in the feed than control. The Growth of Blue gourami was higher in feed IV $(0.54 \pm 0.04)$. Dhanraj et al., (2013) reported that the growth of Koi carp was higher in diet $3(S C D)(0.32 \pm 0.07)$ lower in control (0.19 \pm 0.02$)$. Roy et al. (2013) reported that the growth was higher in Labeo rohita fed with two phytase producing bacterial strains isolated from the gut. Pornthep Niamphithak et al. (2017) reported higher growth in Bocourti Catfish (Pangasius bocourti Sauvage, 1880) fed with Lactobacillus plantarum $\left(1 \times 107 \mathrm{cfug}^{-1}\right)$ in

Table 8. Feed utilization and Growth parameters of Blue Gourami in relation to different bacteria. Each value is the average $( \pm S D)$ performance of 5 individuals in triplicates reared for 21 days

\begin{tabular}{|c|c|c|c|c|c|}
\hline \multirow[t]{2}{*}{ S.No. } & \multirow[t]{2}{*}{ Parameters } & \multicolumn{4}{|c|}{ Experimental Feeds } \\
\hline & & Feed I & Feed II & Feed III & Feed IV \\
\hline 1. & $\begin{array}{l}\text { Feed Consumption(FC)(g/g live } \\
\text { wt/21days) }\end{array}$ & $3.11 \pm 0.41$ & $3.33 \pm 0.31$ & $3.55 \pm 0.16$ & $5.44 \pm 0.13$ \\
\hline 2. & Feed Conversion Efficiency(FCE) & $0.03 \pm 0.01$ & $0.6 \pm 0.02$ & $0.08 \pm 0.01$ & $0.06 \pm 0.01$ \\
\hline 3. & Feed Conversion Ratio (FCR) & $8.41 \pm 0.23$ & $5.60 \pm 0.33$ & $4.4 \pm 0.10$ & $4.46 \pm 0.53$ \\
\hline 4. & Growth (G) (g/g live wt/ 21 days) & $0.22 \pm 0.05$ & $0.33 \pm 0.08$ & $0.44 \pm 0.05$ & $0.54 \pm 0.04$ \\
\hline 5. & Percentage Growth (PG) (\%) & $5.46 \pm 1.62$ & $8.12 \pm 1.05$ & $10.25 \pm 1.37$ & $10.25 \pm 0.09$ \\
\hline 6. & Relative Growth Rate (RGR) & $0.11 \pm 0.06$ & $0.15 \pm 0.02$ & $0.19 \pm 0.02$ & $0.23 \pm 0.20$ \\
\hline 7. & $\begin{array}{l}\text { Assimilation (A) (g/g live } \\
\text { wt/21days) }\end{array}$ & $1.22 \pm 0.05$ & $1.36 \pm 0.15$ & $1.31 \pm 0.30$ & $1.44 \pm 0.32$ \\
\hline 8. & $\begin{array}{l}\text { Metabolism (M) (g/g live } \\
\text { wt/21days) }\end{array}$ & $0.43 \pm 0.42$ & $1.10 \pm 0.11$ & $1.42 \pm 0.41$ & $1.44 \pm 0.22$ \\
\hline 9. & Gross Growth Efficiency (GGE) (\%) & $3.25 \pm 1.32$ & $5.15 \pm 0.23$ & $5.25 \pm 1.02$ & $6.40 \pm 0.25$ \\
\hline 10. & Net Growth Efficiency (NGE) (\%) & $10.25 \pm 0.38$ & $10.22 \pm 0.15$ & $11.33 \pm 2.13$ & $12.46 \pm 2.12$ \\
\hline
\end{tabular}


the diet. Dias et al. (2018) reported that Bacillus cereus improves growth performance of tambaqui Colossoma macropomum. This enhanced growth performance of fish supplemented with probiotics is probably due to an improvement in digestion, as well as an increase in the synthesis and absorption of nutrients (Hoseinifar et al. 2017). As the growth, the percentage growth of Blue gourami was higher in feed IV (10.25 \pm 0.09$)$. Sivakumar et al., (2014) reported that the percentage growth of Common carp was higher in feed $V(51.12 \pm 22.30)$ and lower in the feed I control, $(16.11 \pm 9.53)$. The relative growth rate of Blue gourami was higher in feed IV $(0.23 \pm 0.20)$ and lower in feed I $(0.11 \pm$ 0.06). Roy et al. (2013) reported that the relative growth rate was higher in feed D3 containing two phytase producing bacterial strains isolated from the gut of rohu Labeo rohita. Suganya et al., (2018) reported that the relative growth rate of Zebra fish was higher in feed $V(0.08 \pm 0.02)$ containing $4 \mathrm{ml}$ Pseudomonas sp. and lower in feed I $(0.03$ $\pm 0.01)$. The Assimilation of Blue gourami was higher in feed IV (1.44 \pm 0.3$)$ lower in feed I (1.22 \pm 0.05 ). Assimilation of Platy was higher in Feed $V$ containing about 104 cells of Bacillus subtilis. (Rajan and Revathi, 2011). Metabolism of Blue gourami was higher in feed IV (1.44 \pm 0.22$)$ lower in feed I $(0.43 \pm 0.42)$. The same result was also reported by Suganya et al. (2014) in goldfish. Gross and Net growth efficiency of Blue gourami was higher in feed IV and lower in feed I. Sunil Kumar and Vishnu (2011) reported a similar result when clownfish were fed with Lactobacillus. Pushparaj et al., (2012) reported higher gross and net growth efficiency when Platy was fed with higher levels of Bacillus subtilis in the feed.

\section{CONCLUSION}

From this study, it was concluded that the combination of three isolated bacteria, such as $1 \mathrm{ml}$ Bacillus sp., $1 \mathrm{ml}$ Enterobactor sp., and $1 \mathrm{ml}$. Aeromonas $s p$. can improve the growth of Blue gourami and act as a potential probiotic feed additive.So, it is suggested that the present research work is useful to the ornamental fish farmers.

\section{ACKNOWLEDGEMENT}

Authors thank the Department of Biology, Gandhigram Rural Institute - Deemed to be University for offering Laboratory facilities to carry out this research work.

\section{CONFLICTS OF INTEREST}

The authors declare that there is no conflict of interest.

\section{FUNDING}

None.

\section{AUTHOR'S CONTRIBUTION}

D.G. - Laboratory experiments were conducted starting from a collection of fish, separation and mass multiplication of bacteria, growth studies, and calculations.

P.S - Done experiments related to the production of enzymes by bacteria and antibacterial studies.

M.R.R-The research work was formulated and guidance was given to the first author for execution.

\section{DATA AVAILABILITY}

All datasets generated or analyzed during this study are included in the manuscript and/or the Supplementary Files.

\section{ETHICS STATEMENT}

Fish used in the present research were in accordance with the guidelines of Committee for the Purpose of Control and Supervision of Experiments on Animals [CPCSEA, Ministry of Environment \& Forests(Animal Division), Government of India] on the care and use of animals in scientific research and also approved by the Institutional Ethical Committee for Research on Human and Animal Subject (IECRHAS) from The Gandhigram Rural Institute- Deemed to be University, Govt. of India, Gandhigram, Tamil Nadu, India

\section{REFERENCES}

1. Agustina S, Stamet B. Prayitno, Agus Sabdono, Gina Saptiani. Antagonistic activity of Kelabou fish( Osteochilus melanopleurus) gut bacteria against Aeromonas hydrophila and Pseudomonas sp. AACL Bioflux, 2018; 11(6): 1859-1868.

2. Ali S A. Feed formulation method. Manual of research methods for fish and shell fish nutrition. CMFRI Special publication. 1980; 8: 98.

3. Aly S.M, Abd-El-Rahman, A.M, John, G. Mohamed, M.F. Characterization of some bacteria isolated from 
Oreochromis niloticus and their potential use as probiotics. Aquaculture, 2008; 277: 1- 6. https://doi. org/10.1016/j.aquaculture.2008.02.021

4. Balcazar J.L., de Blas, I, Ruiz-Zarzuela, D. Cunningham, D, Vendrell, D. Muzquiz. The role of probiotics in aquaculture- Review of Veterinary microbiology Research. 2006; 114: 173-186. https://doi. org/10.1016/j.vetmic.2006.01.009

5. Bairagi A, Sarkar Ghosh, K, Sen S.K, Ray A.K. Enzyme producing bacterial flora isolated from fish digestive tracts. Aquaculture International, 2002; 10: 109-121. https://doi.org/10.1023/A:1021355406412

6. Banerjee G, A.K. Ray, F. Askarian, E. Ring. Characterization and identification of enzymeproducing autochthonous bacteria from the gastrointestinal tract of two Indian air-breathing fish. Beneficial Microbes.,2013; 4(3): 277-284. https://doi. org/10.3920/BM2012.0051

7. Banerjee G, A. Nandi, A.K. Ray. Assessment of hemolytic activity, enzyme production and bacteriocin characterization of Bacillus subtilis LR1 isolated from the gastrointestinal tract of fish. Archives of Microbiology, 2016; 199: 115-124. https://doi. org/10.1007/s00203-016-1283-8

8. Banerjee G, Ray A.K. Bacterial symbiosis in the fish gut and its role in health and metabolism. Symbiosis, 2017; 72: 1-11. https://doi.org/10.1007/s00203-016-1283-8

9. Bergey's Manual of Determinative Bacteriology. Williams and Wilkins, 428 East Preston street, Baltimore, Maryland. 21202, USA, 1994.

10. Bisht A, Singh U. P, Pandey N N. Probiotic potential of Bacillus subtilis for enhancing growth in finger lings of common carp (Cyprinus carpio Linnaeus). Indian Journal of Fisheries, 2012; 59(3): 103 - 107.

11. Dhanaraj M, M A Haniffaa, SV Arun Singh, A Jesu Arockiaraj, CMuthu Ramakrishanana, S Seetharamana, R Arthimanjua. Effect of Probiotics on Growth Performance of Koi Carp (Cyprinus carpio). Journal of Applied Aquaculture, 2010; 22(3): 202 -209. https:// doi.org/10.1080/10454438.2010.497739

12. Dias JAR, Higo A Abe, Natalino C Sousa, Marcia V $S$ Couto, Carlos AM Cordeiro, Juliana O Meneses, Fernanda S Cunha, Jose Luiz P Mourino, Mauricio L Martins, Luis AL Barbas, Paulo CF Carneiro, Alexandre N Maria, Rodrigo Y Fujimoto. Dietary supplementation with autochthonous Bacillus cereus improves growth performance and survival in tambaqui Colossoma macropomum. Aquaculture Research, 2018; 1-8. https://doi.org/10.1111/are.13767

13. Hoseinifar SH, Dadar, M Ringo, E. Modulation of nutrient digestibility and digestive enzyme Activities in aquatic animals: The functional feed additives scenario. Aquaculture Research, 2017; 48: 3987-4000. https://doi.org/10.1111/are.13368

14. Jayaraman J. Laboratory manual in biochemistry. Wiley Eastern Ltd., New Delhi, Fourth reprint. 1992; 75 - 78.

15. Jawahar Abraham T Tirthankar Banerjee. Beneficial antagonistic bacteria from Fresh water fishes and culture environment as probiotics in ornamental fish culture. Indian Journal of Fisheries, 2007; 54(3): 311 319.

16. Liu Han, XianwuGuo, Ravi Gooneratne, Ruifang Lai,
Cong Zeng, Fanbin Zhan, WeiminWang. The gut microbiome and degradation enzyme activity of wild freshwater fishes influenced by their trophic levels. Scientific Reports, 2016; 6: 24340. https://doi. org/10.1038/srep24340

17. Mukherjee Anjan, Goutam Banerjee, Piyali Mukherjee, Arun Kumar Ray, Goutam Chandra, Koushik Ghosh. Antibacterial substances produced by pathogen inhibitory gut bacteria in Labeo rohita: Physico-chemical characterization, purification and identification through MALDI-TOF mass spectrometry. Microbial Pathogenesis. 2019; 130: 146-155. https:// doi.org/10.1016/j.micpath.2019.02.028

18. Muge Aliye Hekimoglu, Cuneyt Suzer, Sahia Saka, Kursat Firat. Enzymatic characteristics and growth parameters of ornamental koi carp (Cyprinus carpio Var. koi) larvae fed by Artemia nauplii and cyst. Turkish Journal of Fisheries and Aquatic Sciences, 2014; 14: $125-133$.

19. Paramita Das, Sudipta Mandal, Argha Khan, Sanjib Kumar Manna, Koushik Ghosh.Distribution of extracellular enzyme-producing bacteria in the digestive tracts of 4 brackish water fish species. Turkish Journal of Zoology, 2014; 38: 79-88. https:// doi.org/10.3906/zoo-1205-3

20. Pornthep Niamphithak, Siripavee Chareon wattanasak,Sompong Doolgindachbaporn. Effect of Dietary Supplement of Probiotic (Lactobacillus plantarum) on Growth Performance, Feed Utilization and Survival Rate in Bocourti Catfish (Pangasius bocourti Sauvage, 1880. J Pure Appl Microbiol, 2017; 11(2): 803-809. https://doi.org/10.22207/ JPAM.11.2.19

21. Pushparaj A, Ramesh U, Ambika P. Effect of probionts on the growth and food utilization of clown fish Amphiprion sebae. International Journal of Applied Biology and Pharmaceutical Technology, 2012; 3(1): 309-314.

22. Rajan S, Selvichristy R. Experimental procedure in Life Science, Anjana Book House, Old.28, New Delhi. 16, South Mada street, Koyambedu, Chennai - 600 107, 2010.

23. Rajan M R, Revathi U. Role of Probiotics in Ornamental fish Platy Xiphophorus maculates. J Pure Appl Microbiol, 2011; 5(2): 819-823.

24. Rajan MR, J Jeyachristina Arockiaselvi. Isolation of Intestinal Microflora and its Probiotic effect on Feed Utilization and Growth of Gold fish Carassius auratus. International Journal of Current Microbiology and Applied Sciences, 2014; 3(9): 685-688.

25. Ray A K, K Ghosh, E Ringo. Enzyme producing bacteria isolated from fish gut: a review. Aquaculture Nutrition, 2012; 18: 465-492. https://doi.org/10.1111/j.13652095.2012.00943.x

26. Roy T, G Banerjee, SK Dan, P Ghosh, AK Ray. Improvement of nutritive value of seasame oilseed meal in formulated diets of rohu, Labeo rohita fingerlings after fermentation with phytase producing bacterial strains isolated from fish gut. Aquaculture International, 2013; 22: 633-652. https://doi. org/10.1007/s10499-013-9691-0

27. Shubhankar Ghosh A, D G Selvam, C S Neethu, A V 
Saramma, AAM Hatha. Diversity and antimicrobial activity of Lactic Acid Bacteria from the gut of marine fish Rastrelliger kanagurta against fish, shrimp and human pathogens. Journal of Marine Biological Association of India, 2014; 55: 22-27. https://doi. org/10.6024/jmbai.2013.55.2.01778-04

28. Siva Kumar P, Rajan MR Ramachandran P. Effect of probiotics on growth performance of common carp Cyprinus carpio var communis. International Journal of Pharma and Bio Sciences, 2014; 5(1): 835-839.

29. Sivakumar P, Rajan MR, Balakrishnan R. Enzymatic productivity and Molecular Characterization of Intestinal bacteria of Yellow molly ( Poecilia latipinna) in relation to Growth. International Journal of Information Research and Review, 2016; 3(6): 25522555.

30. Sivakumar P, Suganya D, Rajan MR. Chracterization, digestive enzyme productivity and anti bacterial activity of intestinal bacteria of Rohu Labeo rohita. Asian Journal of Science and Technology, 2017; 8(11): 6468-6477.

31. Somrudee Silarudee, Saowanit Tongpim, Nicha Charoensri, Sompong Doolgindachbaporn, Effect of a Probiotic Lactobacillus plantarum CR1T5 Dietary Supplements on Non-specific Immunity in Black Eared Catfish (Pangasius larnaudii), J Pure Appl Microbiol, 2019; 13(1): 289-296. https://doi.org/10.22207/
JPAM.13.1.31

32. Suganya D, Rajan MR, Siva Kumar P. Isolation, Identification, Enzyme and Molecular characterization of intestinal Bacteria of Goldfish (Carassius auratus) and its Role on Growth. Indian Journal of Applied Research, 2014; 4(7): 9 - 11. https://doi. org/10.15373/2249555X/July2014/3

33. Suganya D, S Anisha Banu, P Sivakumar, M R Rajan. Impact of Probiotics on growth performance of Zebra fish (Danio rerio). International Journal of Current Research and Modern Education, 2018; 3(1): 487-493.

34. Sunil Kumar P, Vishnu P S. Effect of Lactobacillus acidophilus on growth of Etroplus suratensis. Fishing Chimes., 2011; 31(7): 54 - 55.

35. Wang Y, Shilang Yu, Yueyang Wang, Jianfang Che, Liping Zhao, Xianyong Bu, Yuhong Yang. Effect of replacing fishmeal with soybean meal on growth, feed utilization and nitrogen and phosphorus excretion of juvenile Pseudobagrus ussuriensis. Aquaculture Research, 2015; 47: 3145-3155. https://doi.org/10.1111/ are.12765

36. Zapata A A, Lara-Flores M. Antimicrobial Activities of Lactic Acid Bacteria Strains Isolated from Nile Tilapia Intestine (Oreochromis niloticus) Journal of Biology and Life Science, 2013; 4(1): 164-171. https://doi. org/10.5296/jbls.v4i1.2408 